\title{
Rules of Origin and the Web of East Asian Free Trade Agreements
}

\author{
Miriam Manchin \\ Centro Studi Luca d'Agliano (Milan) \\ Annette O. Pelkmans-Balaoing \\ Erasmus University (Rotterdam)
}

\begin{abstract}
The authors provide an overview of the preferential rules of origin in East Asia, highlighting the aspects that might possibly generate some trade-chilling effects. The paper reviews characteristics of existing free trade agreements (FTAs) with special emphasis on lessons from the European experience, and analyzes some important features of the existing rules of origin in East and South-East Asian FTAs. The empirical analysis of the effectiveness of preferentialism on intra-regional trade flows focuses on the ASEAN Free Trade Area (AFTA), with the aim of providing a rough estimate of the costs of requesting preferences. The results suggest that preferential tariffs favorably affect intra-regional imports only at very high margins (around 25 percentage points). This points to the likelihood of high administrative costs attached to the exploitation of preferences, particularly with regard to the compliance with AFTA's rules of origin.
\end{abstract}

JEL Codes: F13, F15, F17

Keywords: Free trade agreements, rules of origin, preferential tariffs, ASEAN Free Trade Area

\section{World Bank Policy Research Working Paper 4273, July 2007}

The Policy Research Working Paper Series disseminates the findings of work in progress to encourage the exchange of ideas about development issues. An objective of the series is to get the findings out quickly, even if the presentations are less than fully polished. The papers carry the names of the authors and should be cited accordingly. The findings, interpretations, and conclusions expressed in this paper are entirely those of the authors. They do not necessarily represent the view of the World Bank, its Executive Directors, or the countries they represent. Policy Research Working Papers are available online at http:/ / econ.worldbank.org.

This is a background paper for the East Asia Rules of Origin project and was funded by EASPR. An earlier version of the paper was presented at the Boao Forum for Asia (BFA) "Regional Workshop on the Importance of Rules of Origin and Standards in Regional Integration" held in Hainan on June 27-28, 2006. We are thankful to Anne Robeniol and Ahmad Syaukat of the ASEAN Secretariat for providing us with data, and other critical information for this paper; to Jerzy Rozanski for undertaking the concordance of the AFTA CEPT tariffs with the WITS tariff data base; to Joseph Francois for his valuable advise and assistance. Address correspondence to: A. Pelkmans-Balaoing, Erasmus University Rotterdam, Burg. Oudlaan 50, H8-31, 3000 DR Rotterdam, Netherlands; email: pelkmans@few.eur.nl. 


\section{Introduction}

The maze of East Asian regional and bilateral free trade agreements (FTAs) that has emerged in the last few years has triggered fears of what the attendant rules and administrative procedures would imply for the cost of doing business in the region. If these agreements are mutually consistent, particularly with regards to rules of origin (ROO), then obviously the marginal costs of a new agreement will be minimal for all parties. The lack of coordination in rule-setting among countries, however, ensures that each trade route marked by preferentialism will be differentially governed, thus leading to mounting information and transaction costs. Moreover, the specter of multiple and overlapping agreements among countries will only further increase the need to regulate trade so that preferences do not spillover unintendedly to non-partners via the member with the lowest trade barriers.

In a sea of preferential agreements, $\mathrm{ROO}$ are, in fact, seen as indispensable since they define the conditions that a product must satisfy to be deemed as originating from the country seeking preferential access. They are principally meant to prevent trade deflection, whereby products from non-participating countries destined for the partner country's market are redirected through free trade partners of the partner country to avoid payment of the partner country's customs duties. However, the problematic intricacies brought about by ROO often work to hinder the flow of goods in the region and introduce new uncertainties in the conduct of trade.

The complexities surrounding the rules of origin could be traced from two sources. One is the difficulty of ascertaining origin in an age of globalized trade and at the same time, increasingly fragmented production processes. When goods are produced in a single production stage then the origin of the products should be relatively easy to establish. Proof that the product was produced in the free trade partner should be sufficient. For other cases, ROO are used to define the methods by which it can be ascertained that the product has undergone sufficient working or processing in the free trade partner to qualify for preferential access. However, technological progress and globalization have made possible the further refinement of division of labor among various producers, in order to exploit scale economies and cost differentials among various countries. Consequently, the production of a single product often encompasses multiple locations, compounding the difficulties of verifying its origin. For most cases, therefore, ROO are used to define the methods by which it can be ascertained that the product has undergone sufficient working or processing in the free trade partner to qualify for preferential access.

The other reason behind the complex design of many ROOs is the convenience in which these rules could be used to both accommodate and conceal protectionist intents. ROOs, by increasing the local content of the product, or by attaching multiple criteria for the satisfaction of origin, could be 
another avenue to effectively exclude product groups from a country's liberalization commitments. Rules can also be made product-specific, so that the extent of protection is hidden in the hundreds of pages of annexes, and coated by technical language not immediately accessible to non-specialists.

Needless to say, the motives underpinning the creation of FTAs, have a direct bearing on the design and degree of restrictiveness of ROOs. For FTAs which are created largely for political and foreign policy purposes, cumbersome ROOs provide an effective means of shielding Members from the economic effects brought about by the removal of tariff barriers. If, on the other hand, the goal of regional import substitution dominates, then ROO can make the conferment of origin conditional on a set of minimum regional content targets, which can spur trade diversion, especially in the use of intermediate manufacturing inputs. The Foreign Direct Investment (FDI) motive, which is present in some FTAs, can exert two opposing pressures. On one hand, it may lead to more restrictive ROOs, as a means to entice rules-evasion on the part of non-partner investors. On the other hand, countries may actually intend to use an FTA to bring down the costs of transactions among members, so as to create a bigger market and a more attractive production base for foreign firms. In this case, the heavy requirements set by ROOs become a genuine hindrance to the achievement of regional goals.

With the proliferation of FTAs observed especially in the last 3-4 years in East Asia, it becomes ever more important to take stock of the implication of these simultaneous agreements on the integration of regional markets. This paper aims in particular to provide an overview of the preferential rules of origin in East Asia, highlighting the aspects that might possibly generate some trade-chilling effects. The paper reviews characteristics of existing preferential trade agreements with special emphasis on lessons from the European experience. This is followed by a brief analysis of the important features of the existing preferential rules of origin in East and South-East Asia. The third part of the paper focuses in on the AFTA and presents an empirical analysis of the effectiveness of its preferential agreement and also provides a rough estimate for the costs of requesting preferences.

\section{Lessons from existing preferential trade agreements}

\section{1 Some main characteristics of preferential rules of origin}

Origin determination

There exist three main approaches to determining origin: change of tariff heading, value-added criteria, and specific manufacturing process requirement. According to the change of tariff heading method the final product has to have a different tariff heading than the inputs used. The second main approach defines a minimum value-added to be done on the inputs in order for the final product to become originating. Finally, specific manufacturing processes can be required to be undertaken in the 
production of the good to be eligible for preferences. Each of these rules has certain advantages and disadvantages with respect to the other rules.

Several agreements require satisfying a combination of two or more methods. For example, not only a change of tariff heading has to be satisfied but also further specific manufacturing processes has to be completed in order to obtain the originating status. For instance according to the EU rules of origin scheme, with the basic rule of change in tariff heading, a country which imports woven cotton fabric (HS 5208) to produce cotton shirts (6105) would satisfy the rule of origin and qualify for preferential reduction of the tariff on cotton shirts. However, in this specific case in EU free trade agreements the change of tariff classification is replaced with a requirement that the product have been manufactured from yarn. In effect this imposes the requirement that two stages of production must be undertaken in the partner or qualifying area to confer origin - not only the sewing together of the fabric but also the production of the fabric itself. Clothing products made in free trade partners of the EU but which are made-up of fabrics imported from third countries, such as China, will not satisfy the EU origin rules and will not qualify for tariff reduction. As origin determination rules become technical they offer scope for the participation of industries in setting restrictive rules of origin (Hoekman, 1993).

While only 13\% of tariff lines in the EU Pan-European Scheme currently rely on the value added criteria (Cadot et al, 2005) due to the outcome of a reform process initiated by the European Commission (EC) in 2003, there are plans to replace the current rules with a single value-added method which the EC expects to be clearer and more development-friendly.

On the other hand, the burden of satisfying the restrictive origin requirements can be alleviated by allowing alternative means to satisfy the rules, thus providing certain flexibility for producers. For example, allowing producers to choose between a value-added criteria or a change of tariff heading, could provide greater flexibility for the traders and would allow them to choose the method which can be satisfied at the least possible cost.

In case the origin requirements are too restrictive then to be able to satisfy rules of origin to achieve preferential market access requires a degree of sophistication on the part of firms in the free trade partner to be able to carefully track and show the origin and movement throughout the company of imported intermediate inputs. It also seems that a modern and efficient customs service is a necessary precondition for the proper implementation of the complex rules of origin. This suggests that countries contemplating free trade agreements should carefully take into account the possible implications of rules of origins for the viability and success of any initiative. The need to avoid complicated technical rules of origin in order to deliver genuine improvement in market access is particularly evident in the European (and North American) experience. A web of free trade 
agreements, in say, Asia, with complex and restrictive rules of origin, may in practice, have little impact on trade flows in final products, and instead bring about a shift in the production and trade pattern of intermediate products, with possible adverse efficiency consequences for resource allocation. Origin determination should have a neutral impact on trade after achieving their basic objective of avoiding trade deflection.

\section{Cumulation}

With cumulation, inputs from preferential trading partners can be used in the production of a final good without undermining the origin of the product. Preferential and free trade agreements can have three different types of cumulation: bilateral, diagonal and full cumulation. For example, bilateral cumulation in NAFTA implies that originating inputs, that is, materials that have been produced in accordance with the relevant rules of origin, imported from the another NAFTA member qualify as originating materials. However, inputs from Mexico used in the production of a final product in Canada, for instance, can be counted originating only if the final product is then re-exported to Mexico but not to the US.

Of greater relevance would be to allow diagonal cumulation on a regional basis so that qualifying materials from anywhere in the region could be used without undermining duty-free access. In other words, parts and materials from anywhere in the region that qualify as originating could be used in the manufacture of a final product which could then be exported duty free within the region. An example is the Pan-European cumulation area which allows diagonal cumulation between member countries.

Finally, there can be full cumulation whereby any processing activities carried out in any participating country can be counted as qualifying content regardless of whether the processing is sufficient to confer originating status to the materials themselves. Full cumulation is applied, for example, in the EU's Cotonou agreement and in AFTA.

Full cumulation could facilitate more fragmentation of production processes among the members of the free trade area and so stimulate increased economic linkages and trade within the region. Some argue that under full cumulation more developed countries can outsource labourintensive low-tech production stages to less developed partners and lock them into these stages, therefore 'blocking' a more wide-ranging process of development. It is argued that diagonal cumulation will stimulate more capital-intensive production processes and investments by requiring more stages of production/higher value-added to be undertaken in the country to fulfil the requirements of rules of origin and obtain preferences. The experience of developing countries under the EU's GSP scheme shows, however, that requiring high levels of value-added or multiple 
processing stages to be undertaken results in lower uptakes of preferences and a lower level of all activities in the country.

\section{Tolerance or De Minimis rule}

These rules allow a specified percentage of non-originating products to be used in the production process without affecting the origin status of the final product. All EU preferential and free trade agreements contain de minimis rules. The percentage allowed in most of the EU agreements is 10 percent (exceptions are the Cotonou Agreement and the agreement with South Africa which allow 15 percent). The tolerance rule under the NAFTA allows that non-originating inputs can be used even if the rule on sufficient processing is not satisfied provided that their value does not exceed 7 percent.

Although the tolerance rule in principle lessens the burden of rules of origin for products with non-originating inputs, the tolerance rules applied to the textiles and clothing sector are often different and less favorable than the general rules of tolerance (Brenton, 2003). Nevertheless, tolerance rules can reduce the often too stringent requirements imposed by the value-added or change of heading requirement and thus lessen the additional production costs which would have to be borne if no tolerance would be allowed.

\section{Duty drawback}

When non-originating materials are used in the production of a final product geared for exports, duty drawback provisions provide a waiving or a repayment of duties applicable to the non-originating material used. However, most preferential agreements do not allow duty drawback thus discouraging the use of third country inputs in the production processes. Some EU FTAs (for example the Cotonou Agreement and the GSP scheme) do not prohibit the usage of duty drawback provisions.

Allowing for duty drawback can reduce the magnitude of trade diversion in forming regional trade agreements. The use of duty drawback can be especially important for countries with intensive trading and production links with manufacturing networks outside the area of the preferential trade agreement. In these cases, the elimination of duty drawback when a preferential agreement is concluded would imply higher production costs for final-good assembly for exports or intermediate processing to partner countries in the PTA. 


\section{Outward processing}

Some preferential and free trade agreements allow for outward processing schemes. Outward processing procedures encourage processing overseas by providing relief from import duties on the compensating value of imports ${ }^{1}$ after processing abroad.

The amount of duty payable is calculated from the value of the product imported multiplied by the appropriate tariff for that product minus the hypothetical duty that would have been paid on the intermediate products exported under the processing scheme. Thus, for example a firm which exports textiles under an outward processing scheme and subsequently re-imports clothing products would have to pay the (preferential or other applicable) duty on the clothing product but would be refunded the duty that would be applicable to the value of the textile products exported.

Within outward processing in textiles and clothing the EU has provided for a specific scheme known as "economic outward processing" where, often up to specific limits and/or subject to surveillance, imports after processing enter the EU duty free. Under this regime, goods temporarily exported from the EU for processing must be in free circulation within the Community and must have EU origin. Although, if products of Community origin are insufficient, derogation can be granted from these rules, but for no more than $14 \%$ of the total value of the goods for which prior authorization is requested. There are further requirements in the regulation to protect the industry in the Community, such as, commitments to maintain production and employment in the Community and maximum processing rules. The latter are the converse of the rules of origin in free trade and preferential trade agreements, which stipulate minimum processing requirements.

Allowing for outward processing in preferential and free trade agreements could ease rules of origin requirements and reduce the impact on re-allocating input sourcing. The EU example suggests that documenting the outward processing scheme is less costly than the documentation requirement of the rules of origin (see a detailed discussion in Brenton and Manchin, 2003) thus the allowance of outward processing within the PTA might reduce the administrative costs for outward processing linkages. Furthermore, outward processing permits greater production fragmentation which can be crucial for the competitiveness of firms.

\section{Documentation of rules of origin}

Administrative costs can vary with different documentation and certification methods. Certification of rules of origin in the $\mathrm{EU}$ is relatively more restrictive involving a two-step private and public certification. On the other hand, NAFTA and other US preferential trade agreements require a singlestep private certification which does not have to be repeated each time. Cadot et al (2005) estimates

\footnotetext{
${ }^{1}$ Compensating value of imports is in other words part of the imports which was previously exported for processing.
} 
that the administrative costs of the Pan-European preference scheme is around $6.8 \%$ while the administrative costs under NAFTA are around 1.9\%. The authors argue that the high difference in the administrative costs between the two regimes is mainly attributable to the different certification method used in the two schemes implying that the self-certification used in NAFTA is less burdensome for traders. These results indicate that authorities should be careful in designing the certification process of rules of origin as it can significantly increase the costs of requesting preferences and thus reduce the potential positive impact of trade integration.

\subsection{Costs of proving and satisfying origin}

The complexities of all the above requirements contribute to important costs of satisfying origin requirements. The restrictiveness of satisfying rules of origin may also be compounded by the costs of actually proving origin. In a widely quoted study Herin (1986) found that the costs for EFTA producers of proving origin led to one quarter of EFTA exports to the EU paying the applied most favored nation (MFN) duties. Herin (1986) estimates the costs of documentation and administration of origin rules to be equivalent to some 3 percent of the value of the goods traded. A more recent study by Carrière and de Melo (2004) finds that total compliance costs for Mexican traders exporting to the US averaged around 6 percent in 2001. Using a double-censored Tobit estimation technique, they obtained a compliance cost estimate of 3.9 percent for products where the utilization rate is below 100 percent. Estimating the costs for NAFTA, Cadot et al. (2005) estimates the trade-weighted compliance (administrative) costs to be 6.8\% (1.9\%) and for the Pan-European preference scheme to be around $8 \%(6.8 \%)$. In another empirical work assessing EU preferences Manchin (2006) finds the costs of requesting preferences in the case of Cotonou preferential scheme for non-least developed ACP (African, Caribbean and Pacific) countries to be around 4 percent. The findings of these studies highlight that the costs of obtaining preferences can be substantial. Thus as the increasing multilateral liberalization process leads to lower MFN tariffs the benefits offered by preferential trade agreements are decreasing and become marginal if the costs of obtaining these preferences remain high.

The costs of proving origin involve satisfying a number of administrative procedures so as to provide the documentation that is required and the costs of maintaining systems that accurately account for imported inputs from different sources to prove consistency with the technical rules. The ability to prove origin may well require the use of, what are for small companies in developing and transition economies, but not for companies in developed countries, sophisticated and expensive accounting procedures. Without such procedures it is difficult for companies to show precisely the geographical breakdown of the inputs that they have used. The costs of proving origin may be even higher, and possibly prohibitive, in countries where customs mechanisms are poorly developed. Thus, even if producers can satisfy the rules of origin, in terms of meeting the technical requirements, they 
may not receive preferential access to the EU because the customs authorities do not accept their proof of origin or the costs of proving origin are high relative to the duty reduction that is available. The latter suggests that the economic impact of preferential tariff reduction may be discontinuous. Initial reductions in tariffs will have little impact since they will be less than the costs of proving origin. It is only once the gap between the preferential tariff and the MFN rate exceeds the costs of proving origin that there will be a stimulus to trade.

The burden of production costs induced by restrictive rules of origin can be somewhat reduced by allowing less restrictive cumulation rules (such as diagonal or full cumulation), allowing duty drawback, outsourcing and higher de minimis levels. Furthermore, administrative costs can be also reduced by more trader 'friendly' approaches, such as using self-certification methods. Estevadeordal and Suominen (2005) conducting an analysis on the implications of rules of origin for trade based on a sample including 155 countries and find that rules of origin regimes with the above measures foster bilateral trade compared to rules of origin regimes which do not allow duty drawback, outsourcing, less restrictive cumulation, higher de minimis rules.

\section{Rules of origin in East and South-East Asia}

\subsection{An overview of the main Rules of Origin provisions in East Asian FTAs}

In a recent survey of ROOs worldwide, Estevadeordal and Suominen (2004) observed that Asian FTAs, such as the ASEAN Free Trade Area (AFTA), Australia-New Zealand Closer Economic Relations Trade Agreement (ANZCERTA)2, Singapore-Australia Free Trade Agreement (SAFTA), and the South Pacific Regional Trade and Economic Cooperation (SPARTECA) in the Asia-Pacific, stand out for their generality. However, the propensity to expand the existing FTAs to new members or create new country-combinations of FTAs, increasingly introduce product-specificities in the design of ROOs. This can be seen in new arrangements such as the ASEAN-China FTA and the recently signed ASEAN-Korea FTA.

The relatively ample allowance for imports in the AFTA stems from the realization that for many heavily-traded products in the region, like electronics, production processes may be so splintered that the value of local content is often a small percentage of the product's total value. Very early on in the formation of AFTA, it was recognized that the 40\% ASEAN origin rule may often not be met in the case of trade in textile and textile products. In 1995, it was therefore decided that either the percentage value-added or the substantial transformation rule may be used by ASEAN exporters. The AFTA ROO underwent further overhaul, starting in 2003, when operational procedures were further clarified and simplified. In the same year, the decision was reached to adopt a change in tariff heading

2 CER (Closer Economic Relations), CEP (Closer Economic Partnership), SEP (Strategic Economic Partnership), are all names used interchangeably with FTA. 
rule for determining the origin of the product as a general alternative rule "applicable to all products which cannot comply with the $40 \%$ local/ASEAN content requirement, giving priority to sectors which are the subject of private sector requests and those sectors prioritized by the AEM for accelerated integration" (AFTA Council, 2003) ${ }^{3}$. As of last year, the change of tariff heading rule is fully endorsed for four sectors: wheat-flour ${ }^{4}$, wood-based products, aluminum products and iron and steel ${ }^{5}$.

The ASEAN-China Free Trade Area (ACFTA) adopts the same general value-added rule of the AFTA of $40 \%$ local/regional content with full cumulation. The Agreement on Trade in Goods is currently in force, which extends the liberalization commitments from the limited 'Early-Harvest' agricultural products (HS chapter $01-08$ ), to the rest of the traded sectors in the normal inclusion list. As in the AFTA ROO, an alternative change of tariff heading criteria can be invoked for a number of products. ${ }^{6}$ In the case of ACTFA, the rule applies for 424 (HS6) textile and textile products items, 2 items of preserved fish, 6 items of wool, 22 of leather goods, 14 for furskins and 4 item lines of footwear. It is only in 5 wool tariff items, that the change of tariff heading is set as the exclusive rule. ${ }^{7}$

The ASEAN-KOREA Free Trade Area (AKFTA) is the most recent agreement that has been concluded (May 2006), although Thailand, Cambodia and Myanmar has not yet signed due to the current political instabilities in Thailand ${ }^{8}$, and the unfinished negotiations for the inclusion lists for Cambodia and Myanmar. The general 40\% value-added local-regional content of AFTA and the ACTFA is extended to this free trade area, as well as the full cumulation rule. Surprisingly, AKTFA emerges now as even more liberal than the AFTA because the change of tariff heading, as an alternative rule to the $40 \%$ content requirement, is applicable to a greater number of products relative to the coverage in the AFTA and the ACTFA. A novelty has also been introduced in the AKTFA, namely, the back-to-back Certificate of Origin (CO), which allows the conferment of preferences to the re-exports of partner $A$ into partner $B$ of products first exported by partner $C$ into $A .{ }^{9}$ This is particularly advantageous for countries engaging in substantial entrepot trade such as Singapore.

\footnotetext{
${ }^{3}$ In November 2004, 11 priority sectors were identified for deeper integration where tariffs will be eliminated in at least 85\% of the products in 2007 for ASEAN-6, and 2012 for Cambodia, Laos, Myanmar and Vietnam. These sectors are: agro-based products, automotive products, electronics, fisheries, rubber-based products, textiles \& apparels, wood-based products, e-ASEAN, health care, tourism and air travel. See http://www.aseansec.org/15070.htm for AFTA Council reports.

${ }^{4}$ For wheat-flour products, change of tariff heading is the sole origin criterion.

5 Product-specific rules are negotiated only upon the request of private sector groups.

${ }^{6}$ Negotiations are still on-going for the product specific rules of other sectors. Only the specific ROOs are finalized in sectors under the normal inclusion list.

7 See Annex 3, Attachment B of the ASEAN-China FTA Agreement (http://app.fta.gov.sg/data//fta/file/ACFTA Annex3.pdf).

${ }^{8}$ Another reason is the protest issued by Thailand due to Korea's exclusion of rice in the agreement. Thailand is the world's biggest exporter of rice.

9 Singapore imports, say, 10 units of televisions from Korea, where the preferential duties apply under the AKTFA. A back-to-back certificate allows Singapore to re-export, for instance, 7 of those units to ASEAN, and
} 
For Singapore FTAs, such as the one signed with Japan (JSEPA) ${ }^{10}$, the degree of restrictiveness of the ROO largely reflects the sensitivities of Singapore's partners. Agricultural products and textiles and apparel are characterized by particularly complex rules even if 384 agricultural items are excluded, constituting $90 \%$ of total Singapore exports to Japan. ROOs are product specific, relying mostly on the change of tariff heading rule ${ }^{11}$. For some products an alternative RVC rule is allowed, albeit at a high rate of $60 \%$. In cases where RVC is an additional criterion to be satisfied, the content requirement is lower at $40 \%$. However, about half of the tariff subheadings in the agreement already have duty-free MFN status, so that in practice, ROOs' effect is quite limited. De minimis is permitted, also varying across products. Outward processing is recognized in all of Singapore's FTAs, allowing it to count the value of the outsourced part of the production process as Singaporean production.

The Korea-Singapore FTA follows the same pattern of product specificity of the JSEPA, also with the change of tariff heading rule as the dominant origin criteria. For some products an additional RVC of $45 \%, 50 \%$ or $55 \%$ is asked, and for a few items, the RVC rule alone will suffice. The sensitivity of textiles is seen in the added details in the description of transformation rules, and in its exclusion from the $10 \%$ De Minimis rule.

In contrast, a general value-added rule of $40 \%$ is applicable to all products under the Agreement of New Zealand - Singapore for Closer Economic Partnership (ANZSCEP). Both countries are parties to yet another FTA, the Trans-Pacific Strategic Economic Partnership Agreement (TRANSEP), which was formed in June 2005 together with Brunei and Chile ${ }^{12}$. Under this agreement, ROOs contain product specific change of tariff heading rules, with some products having an additional RVC provisions ranging from $45 \%$ to $50 \%$, as in the case for textiles and footwear. Still, for some products, the CTC and RVC are alternative rules. Goods that are unable to meet any of the ROO criteria, origin may still be conferred provided that the non-partner content do not exceed $10 \%$ of the goods' value. In effect, the product specific rules apply only to the trade between Chile and the rest of the TRANSEP countries, and between Brunei and New Zealand, since a

still be able to avail of the same preferential rates any ASEAN member would impose on Korean-made televisions.

${ }^{10}$ Japanese FTAs are incorporated in an 'Economic Partnership Agreement ' (EPA), which has a broader scope than the typical FTA, such as e-commerce, financial services, information and communication technology and Human Resource Development.

${ }^{11}$ Heading changes are needed for HS 01- 24, HS 38 (chemical products), HS 85 (machinery), while subheading or value content requirements for liquor and cordials apply. For the rest a RVC requirement of $60 \%$ with a combination of subheading changes is needed. The yarn-forward rule applies for textile fabrics and articles (HS 59).

${ }^{12}$ Trans-Pacific SEP was previously known as the Pacific Three Closer Economic Partnership (P3-CEP). Its negotiations was first launched at the 2002 APEC Leaders Summit by leaders of Chile, Singapore and New Zealand. Brunei first took part as a full negotiating party in the fifth round of talks in April 2005. 
general value-added rule apply for the other pairs of countries under the ANZSCEP agreement between Singapore and New Zealand, and also under the AFTA between Brunei and Singapore.

Australia's FTA with Singapore (SAFTA), is less general than the ANZSCEP since a valueadded requirement of $30 \%$ is imposed for some products (110 HS8 tariff lines mostly in HS 84-85) while for the rest a higher 50\% local/regional content is required. For some 152 tariff lines an additional requirement is imposed that the last process in the manufacture of the product must take place within the territories of the party seeking the preference.

As opposed to the generality and the broad scope of the Singapore- New Zealand FTA, the agreement between Thailand - New Zealand (THAINZCEP), and Thailand- Australia (TAFTA) contains specific rules for all products. The CTC rule is once again predominant, with some products allowing a change in subheading. Additional RVC requirement of $50 \%$ for THAINZCEP and 55\% for TAFTA are imposed mostly for textiles and textile materials. Clothing is further restricted by making origin conditional on the performance of essential processes, such as cutting and sewing. In the case of TAFTA, transformation from specific headings and subheadings is excluded for some products.

The ROO of the Australia - New Zealand CER (ANZCER) has undergone a major revision early this year (to take effect in January 2007). ${ }^{13}$ The RVC rule of $50 \%$ previously applies to all products. The new CTC/ change of tariff heading approach has been adopted, although the RVC rule of $45 \%$ is still the exclusive criteria for some textile sectors such as those in men's and boys' apparel.

The new bilateral agreements reached by Japan with individual ASEAN Members are intended to be incorporated (as annexes) in the ASEAN-Japan FTA (AJEPA), which will not be open to renegotiation once the negotiations for the ASEAN-Japan FTA are completed. The JapanMalaysia Economic Partnership Agreement (JMEPA), is the first to be concluded under this foreseen trajectory towards an AJEPA. It is, as the JSEPA (with Singapore), largely based on the change of tariff heading rule, and with a high degree of product specificity. Even the De Minimis rule varies according to product categories. Once again, for some sectors the RVC rule $(40 \%-50 \%)$ is an alternative, while for some, it is the sole criterion for conferring origin. The novelty in the JMEPA is that for some products the change of tariff heading rule is only valid if the non-originating material is sourced from any of the ASEAN country. This is most likely done in anticipation of possible cumulation rules under the future AJEPA.

Table 2 describes the main features of the rules of origin described above, covering the FTAs in East Asia that has been signed, and those whose full documentation has been released to the public, including annexes.

13 Under the agreement, exporters can still choose to use the old RVC rule till 2012. 


\subsection{Some problems surrounding the use and implementation of ROOs}

The test of the efficacy of a FTA in inducing intra-bloc trade is the extent in which preferences are taken up by the business sector. In AFTA, no data on the utilization rate is available because of the lack of proper reporting of intra-ASEAN imports that were given origin certifications (i.e. imports accompanied by Form $\mathrm{D}^{14}$ ). According to the Bureau of Economic Integration of the ASEAN Secretariat, there is not one single year since the CEPT Scheme began in 1993, where Form D data is available for all 6 original AFTA countries ${ }^{15}$. However, estimates based on firm interviews conducted for the ASEAN Secretariat, show a low utilization rate of about 5\% of total trade. Although preference under-utilization is not unique to ASEAN, this estimate is certainly low relative to the known record of other discriminatory schemes. Brenton and Manchin (2003), for instance, reported that $35 \%$ of eligible exports from the CEEC countries enter the EU using the available preferential rates. Inama (2003), examined the utilization of the General System of Preferences (GSP) of the QUAD countries, and found that of the $62 \%$ of imports of Quad countries originating from all beneficiaries of GSP schemes covered by preferences, $39 \%$ of these were effectively traded under the lowest available rates.

For AFTA and ANZCER that relies on the RVC rule, one reason may be traced in the inability of exporters to cumulate the necessary local / regional content given the degree of process fragmentation in highly globalized sectors such as electronics. Table 1 provides an indication of the extent of this problem, showing the import content of key manufacturing sectors in ASEAN and other East Asian countries. Calculations are based on data taken from the GTAP 6 database for 2001, the latest year available. As expected the import content of electronics and machineries are the highest for ASEAN, the sum of the direct and indirect import content being $67.8 \%$ and $60.6 \%$, respectively. The share of imports is particularly high in these sectors for Singapore and Malaysia. The figures reported here are most likely understated since the data do not differentiate between output destined for local consumption and output for exports. One would expect the import content for exports to be higher than for those sold in the local market because of various fiscal incentives (i.e., import duty drawbacks), which is available for export production in most countries.

Another main culprit tagged as being responsible for the under-utilization of preferences is the complexity of administering and complying with the ROO. LDC exporters are particularly burdened by high compliance cost, not to mention the more fundamental difficulty of local sourcing to meet whatever RVC requirements are imposed. Brenton (2003), for instance, partly attributes the under-

\footnotetext{
14 The total amount of intra-ASEAN imports seeking preferential rates under the CEPT Scheme can be extracted from the Form D certificates.

15 Brunei, Indonesia, Malaysia, Philippines, Singapore and Thailand.
} 
utilization of the EBA agreements to ROO, which are generally stricter relative to those contained in the ACP preferences.

The initial trend in East Asia, as shown by the AFTA and ANZCER agreements is an application of a value-added content rule across all products. In terms of transparency and clarity, a general rule is clearly more desirable relative to specific product rules. Feedback of AFTA exporters, however, reveals the difficulties posed by the computation of costs, the invoicing and other documentation demands inherent in the RVC rule. Customs valuation that differ across countries is another problem, and while continues efforts are being made to address the problem, ${ }^{16}$ it will take a considerable amount of time before the decision to harmonize, undertaken in the highest policy level, is translated into daily practice in all trading ports.

In the AFTA, the emphasis is on pre-export inspections, usually performed by the local trade ministries. Exporters are usually expected to submit a cost analysis of the product with accompanying invoices and documentation and the actual certificate (i.e. Form D, in AFTA's case) needed to request for preferences will then be issued by the Trade Ministry upon verification of the product costs. ${ }^{17}$ Transactions remain very time-intensive, as face-to-face contact with various ministry and customs officials is still the norm, rather than the exception. Once origin is established in the exporting country, preferences are conferred to incoming goods, which would then be randomly subjected to post-audit checks. In theory, coursing products in ASEAN through the "green lane"18 provide traders in AFTA goods substantial benefits in the form of expeditious release of cargo, and overall lower administration costs. In practice, however, some traders avoid the green lane on purpose because products entering through this window are said to be more likely to be subjected to extensive post-audit checks. ${ }^{19}$ The so-called "red lane" with ordinary clearance examinations is preferred instead. This is an example of a trade-facilitating device, such as the post-audit system, turning into a source of uncertainty that hinders trade.

The implementation of the RVC criteria is particularly problematic in the absence of automation, clear, harmonized rules and readily accessible conciliation or objection procedures. The

\footnotetext{
${ }^{16}$ In AFTA, the different tariff classification adopted by members is a particular problem. This was addressed in 2004, when a common ASEAN tariff nomenclature (ASEAN Harmonized Tariff Nomenclature, or AHTN) came into force. Another project is the ASEAN Single Window which involves the computerization of clearance procedures with common formats fulfilling the requirements of the international rules of WCO (World Customs Organization) and WTO. The project is still currently being pilot tested between Malaysia and the Philippines.

17 Pre-export inspections are meant to check the conformity of the product with the rules of origin. It must also verified whether statements in the Certificate of Origin correspond to the supporting documentary evidence submitted. Finally the descriptions, quantity and weight of goods, marks and number of packages, as specified must be seen to be conforming to the products to be exported.

18 The 'Green Lane' system allows the importation of ASEAN-origin products without extensive examination.

${ }^{19}$ Based on interviews done by the Japan External Trade Organization (JETRO) of Japanese firms active in the region (JETRO, 2004).
} 
actual valuation of costs thus heavily depends on the judgment of individual customs officials, and this even more in an environment where contesting the rulings would imply more costly delays without any certainty of neutral arbitration. Self-certification is one solution, which was in fact, proposed by Australia, Korea, China and Japan in their respective FTA negotiations with ASEAN. However, the notion of self-certification is alien to the culture of customs inspection in ASEAN.

The potentially cumbersome procedures involved in the valuation and certification of declared costs under the RVC rule, may have prodded ASEAN to follow the example of ANZCER in shifting to the CTC criteria for all products. As mentioned earlier, the ASEAN-Korea FTA (AKFTA) is now more flexible than the AFTA since the change of tariff heading alternative is available for all products. For products where the preferential tariffs under the AKFTA approximate the levels found in AFTA, then preferences in the latter will be eroded by the more liberal rules offered by the former.

This trend towards product specific rules is not without risks, however. What may begin as a facilitating measure may eventually be used to introduce protectionist restrictions. This can be done by excluding inputs from certain tariff headings, attaching an essential process in the transformation of the product or turning the RVC as an additional instead of an alternative rule to satisfy origin. Bilateral FTAs with restrictive product specific rules will also most likely define the parameters of wider FTAs formed later on, as in the case of the Japan-ASEAN EPA.

For FTAs such as AFTA which group together relative high-tariff countries with a duty-free member such as Singapore, avoiding trade deflection will always be a difficult challenge, given the complexities of verifying the origin of goods produced or assembled from multiple locations worldwide. The burden of proper verification becomes all the more taxing in an environment where the proliferation of bilateral FTAs lead to numerous potential 'backdoors' that need effective policing. Clearly, the likelihood of trade deflection increases when relatively high tariff countries like Thailand or the Philippines also acquire pockets of low barriers. This in turn might lead to more intensive or heavy-handed verification procedures that will further hike administrative and waiting costs. If implementation indeed becomes too difficult, leading to the inability to arrest a significant amount of trade deflection, then this may have a direct adverse consequence on the level of domestic political support for the FTA.

The lack of coordination in setting ROOs amidst the proliferation of FTAs also has a political cost attached to it, namely the cost of choosing favorites among favorites. It is not surprising that different permutations in the exchange of concessions among countries result to ROOs with varying degrees of restrictiveness, which in turn lead to a sort of hierarchy of partners not unlike the EU's socalled pyramid of preferences. History is replete of examples of how differentiating partners into friends, lesser friends and foes has bred all sorts of animosities, and has certainly not created an environment conducive to the development of closer or strategic economic partnership. The recent 
surge of FTAs in East Asia is said to be less about trade and more about issues like trade facilitation or regulatory barriers involving investments and services, where negotiations have bogged down in the multilateral arena. It is not unlikely that irritations stemming from contentious ROO negotiations, or the uneven restrictions applied to trade among different partners, could spill-over to more important, high-stake negotiation areas.

\section{Empirical analysis of the importance of preferences in AFTA}

The objective of this empirical analysis is to explore the effects of preferences on trade flows and to provide an approximate estimate for the costs of requesting preferences under AFTA by concentrating the analysis on disaggregate trade flows which are eligible for preferences. Due to the non-availability of data which would distinguish between trade flows which obtained preferences and flows which did not we carry out the analysis using normal trade flows. While the obtained estimates do not provide a precise quantification of the costs of preferences due to these data limitations, we nevertheless are able to obtain an estimate of the importance of preferences for trade flows and of the minimum level of preferences needed in order to have a positive trade stimulating effect on intraAFTA trade flows.

Data availability constrains us to limit the analysis to the period of $2001-2003$. The analysis is conducted at 6-digit HS level and includes Indonesia, Malaysia, Philippines and Thailand as reporting countries and the same four countries and Singapore as partner countries. The decision to focus on only four countries is due to the fact that preferences no longer matter for Singapore and Brunei given the predominance of zero MFN tariffs. The new members, on the other hand, are yet to fully implement the CEPT scheme ${ }^{20}$, and together account for a small share in intra-ASEAN trade. Thus we excluded those trade flows for which the third country tariffs were zero or equal to the preferential tariff. The data covers the period 2001-2003 which yields a database of 42,268 observations on bilateral trade flows. ${ }^{21}$ Data on geographical variables were obtained from the Paris based Centre d'Etudes Prospectives et d'Informations Internationales (CEPII).

To measure the importance of trade preferences on intra-ASEAN trade flows we use a gravity model which explains the volume of bilateral trade flows between countries. The origins of the model date back to Tinbergen (1962) and Pöyhonen (1963) and the theoretical derivation of the gravity model has been further developed by Anderson (1979), Bergstrand (1985), Deardorff (1995), Eaton and Kortum (2002), Anderson and van Wincoop (2003). Anderson and Wincoop (2003) argue that bilateral trade flows depend on the destination and origin price effects, which are themselves related to the

\footnotetext{
${ }^{20}$ Cambodia, Laos, Myanmar and Vietnam have later deadlines to implement the CEPT scheme: Vietnam by 2006, Laos and Myanmar by 2008 and Cambodia by 2010.

21 Data for Thailand for the year 2001 is not available.
} 
existence of trade barriers, which they call "multilateral resistance". They propose a method which consistently and efficiently estimates gravity equations by controlling for price effects in both the destination and origin markets (and for other regional specificities which would be omitted) by including origin and destination fixed effects in all equations. Since our dataset ranges over time, prices should also change over time. To control for these changes, we therefore include origin and destination fixed-effects, interacted with time dummies. ${ }^{22}$

The analysis requires a variable which would capture the otherwise omitted price effects. Prices are expected to be different in each sector, thus to correctly account for price effects we include time varying country specific fixed effects interacted with sectoral dummies. ${ }^{23}$ The following specification is used for the regression:

$$
\begin{aligned}
& \ln X_{i j k t}=\alpha+\beta_{1} \ln P R E F_{i j k t}+\beta_{2} \ln D_{i j}+\beta_{3} \text { Language }_{i j t}+\beta_{4} E_{i t k}+\beta_{5} I_{j t k}+\beta_{6} T_{t}+ \\
& +\beta_{7} S_{k}+u_{i j k t}
\end{aligned}
$$

The dependent variable $X_{i j k t,}$ is the bilateral import from country $i$ to country $j$ in period $t$ of product k. Country $i$ and $j$ are limited to 5 ASEAN countries, namely, Indonesia, Malaysia, Philippines, Singapore and Thailand and products $k$ are limited to those for which there is an applicable preferential tariff according to the AFTA. The specification is very similar to those of the aggregate regressions. The main difference is that instead of using bilateral preferential tariffs or MFN tariffs, we include the preference margins (the difference between MFN and preferential tariffs relative to MFN tariffs) in the regressions. The variable PREF captures the impact of different preference margins on bilateral trade flows, and is constructed in the following way:

$$
P R E F=\ln \frac{(M F N-P T)}{(1+M N F)} * \text { Difference }
$$

where $P T$ is the preferential tariff, $M F N$, the third country tariff, and Difference stands for several dummy variables which capture the difference between MFN and preferential tariffs. A total of fifteen dummy variables were interacted with the preference margin, each created for every $5 \%$ differential in MFN and preferential rates, all the way up to $50 \%$ margin, after which dummies correspond to margins of $10 \% .{ }^{24}$ The coefficient of the preference margin interacted with these dummy variables, thus indicates the region of tariff differentials where an impact on bilateral trade flows can be expected to take effect. $E_{t i k}$ and $I_{i t t}$ are time varying reporter and partner fixed-effects

\footnotetext{
22 See Francois and Woerz (2006) using similar specification.

${ }^{23}$ Chen (2004) also uses sector and country specific fixed effects to capture price effects in each sector and country, however she has a cross-section data and therefore she does not use time varying fixed effects.

${ }^{24}$ In other words the fifteen dummies capture when the difference between third country tariffs and MFN tariffs are $0-5 \%, 5-10 \%, 10-15 \%, 15-20 \%, 20-25 \%, 25-30 \%, 30-35 \%, 35-40 \%, 40-45 \%, 45-50 \%, 50-60 \%, 60-70 \%, 70$ $80 \%, 80-90 \%$, or more than $90 \%$.
} 
interacted with sectoral dummies, while $T_{t}$ and $S_{k}$, correspond to time fixed effects and sector specific fixed effects, respectively.

Results

From the results presented in table 4, it is apparent that distance has a smaller negative effect on intra-ASEAN trade than what is usually found in the literature. Although high internal land transport costs are said to characterize much of ASEAN, port logistics between the main regional trade routes (largely involving Singapore) are believed to be cost efficient.

Turning to the role of preferences, fifteen variables were included in the regression to capture the importance of preference margin on trade flows. Results reveal that the preference margin has a negative significant effect on trade when the difference between third country tariffs and preferential tariffs are lower than 5 percent. This might be because of the costs of requesting the preferences, such as administrative costs, and the costs of complying with the rules of origin requirement of the preferences are higher than the benefits would be from obtaining preferential treatment. When the difference between preferential and MFN tariffs are between 5 to 10 percent, the coefficient remains negative but becomes insignificant. While margins of 10 to 25 percentage points register a slightly positive effect, the coefficient is insignificant. Preferences start to have a trade stimulating effect only when preferential tariffs are at least 25 percentage points lower than the MFN rates. These results suggest that the costs of requesting preferences within AFTA might be in the range of $10-25 \%$. Nevertheless, one has to bear in mind that these results are not based on actual utilization rates but normal intra-regional trade flows which do not take into account whether preferential tariffs were actually applied or not.

The cost estimates obtained are somewhat larger than those found in the literature for other preference schemes. Estimates for EFTA countries by Herin (1986) are around 3\%, for other EU schemes the range of estimates is between 4-4.5\% (see Manchin 2006) and 6-8\% (see Cadot et al., 2005). Cost estimates for NAFTA are around 6\% (see Carrère and de Melo, 2004). Estimates that the costs of documentation and the administration of origin rules, which is the principal part of increased costs for preferential trade, impose costs on exporters equivalent to some 3 percent of the value of the goods traded in the case of EFTA countries. Manchin (2006) finds that costs of requesting preferences for ACP countries under the Cotonou preference scheme of the EU is around 4-4.5 percent of the value of goods traded. More recent work on NAFTA by Carrère and de Melo (2004) finds that average total compliance costs were $6.2 \%$ in 2001 . Using double-censored Tobit estimation techniques, they 
obtain a compliance cost estimate of $3.9 \%$ for products where the utilization rate is below $100 \% .25$ Estimating the costs for NAFTA, Cadot et al. (2005) estimates the trade-weighted compliance (administrative) costs to be $6.8 \%(1.9 \%)$ and for the Pan-European preference scheme to be around $8 \%(6.8 \%)$.

Interestingly, for products with very high preference reduction, the impact of preferences is reversed and turns negative. The immediate explanation that comes to mind are the presence of NTMs that inhibits trade, the negligible supply of the product within the region, or redundancy due to other regional import substitution instruments in place.

A dummy variable was included in the regression (see second column in Table 4) capturing the effects when traders can choose between satisfying the value-added requirement or an alternative rule requiring specific production processes to be performed in order to obtain the originating status for the product. The variable is significant and the coefficient is negative indicating that trade in these products is lower than what would be normally expected. The results imply that even with providing an alternative rule for origin determination the requirements for obtaining originating status for these products might still be too restrictive. It is also true that ASEAN sources its textiles imports largely from outside the region such as China, US, EU and South Asia. This would imply that the amount of preferential margins given textiles, are insufficient to alter the competitive position of regional producers vis-à-vis their non-ASEAN counterparts.

Table 5 examines in detail some of the products that register the highest margin of preferences, looking at the incidence of non-tariff measures, and the value of imports as a share of total intra-ASEAN trade. For Thai imports of women's / girls' silk blouses (HS 620610) from ASEAN, for instance, a preference margin of 60 percentage points is applicable, but out of the total imports of Thailand for this product, only $5.58 \%$ is sourced from ASEAN. In fact, for half of the product groups in this list, trade shares hover around the 1 percent range. This propensity to extend high preferences on products where little or no intra-ASEAN trade takes place is sometimes referred to as the 'snow-plough' effect (Menon, 2005), referring to the failed ASEAN Preferential Trading Arrangement ${ }^{26}$ where preferences are given mostly to trade-irrelevant products such as snow-ploughs. Incidentally, a remnant of this proverbial example can still be seen here: (HS 870310), vehicles especially designed for traveling in snow.

\footnotetext{
25 See also Anson et al. (2005), who estimate that in the case of NAFTA average compliance costs are around 6 percent, offsetting the preferential tariff differential of about 4 percent. Administrative costs chewed up about half of the value of preferential access for Mexican firms.

26 The ASEAN Preferential Trading Agreement (PTA) was instituted in 1977.
} 
Countries that confer the highest margins also appear to be the ones that impose non-tariff measures on these same products. Indonesia, Malaysia, Philippines and Thailand, for instance, offer high margins for vehicles in the HS 870310 category, but all four countries likewise impose non-tariff measures on that product. Malaysia also imposed quantity control measures on vehicle products, some of which register the highest margins found in ASEAN (148\%). The coincidence of large tariff discounts and NTMs, clearly reveal the remaining areas of import substitution which are resistant to liberalization even if limited to AFTA countries.

The only high margin item in table 4.5 with a large share in total intra-ASEAN imports is vehicle bodies (HS 870710), 97\% of which consists of Malaysian imports from Thailand. Here, imports are mainly driven by an industrial complementation scheme ${ }^{27}$, wherein the buyer, source, and brand are pre-specified under the terms set by the said regional program. Other than tariff preferences, products included in this program also enjoy local-content accreditation, and other nontariff incentives. The large margins observed here for vehicle bodies are therefore likely to be redundant, and moreover, they originate not from the importer, which is Malaysia, but from the principal exporter, Thailand. The substantial differential in preferences in this case therefore merely reflects Thailand's import substitution policy in this sector, as shown by the high MFN rates of $80 \%$.

Mapping trade values into various categories of differentials between MFN and CEPT rates, one notes that the largest bulk of intra-ASEAN5 imports fall into category for which preferences do not have a significant effect on trade. This can be gleaned in table 6 which presents the share of imports eligible under three ranges for preferential tariffs margins: 60\% and above; between 60 and $25 \%$; and more than $0 \%$ but less than $25 \%$. Only about $8 \%$ of eligible trade flows fall into the category where preferences may have a positive trade stimulating effect, representing about $3 \%$ of total intra-ASEAN28 imports of Indonesia, Malaysia, Philippines and Thailand.

One important reason for preference underutilization in ASEAN may be found in the nature of the regional production chains where non-ASEAN import content could be very high. Significant part of the manufacturing sector in ASEAN has been established through FDI by multinationals who bring in major components from parent companies outside the southeast Asian region. Although the rules of origin of AFTA requiring at least $40 \%$ cumulative regional content could be considered relatively liberal compared to some other regional agreements due to full cumulation and the relatively lower value-added required, electronics and electrical products, for instance, which make up approx $40 \%$ of intra-ASEAN trade, typically have an ASEAN value added component of only $8-15 \%$ (Dennis and Yusof, 2003).

${ }^{27}$ The Brand-to-Brand Complementation Scheme was set in 1988 to encourage joint production in ASEAN. This was later phased out in 1995 and incorporated into a new ASEAN Industrial Cooperation (AICO) Scheme.

${ }^{28}$ Intra-ASEAN imports are limited to imports from Indonesia, Malaysia, Philippines, Thailand, and Singapore. 


\section{Conclusions}

Proliferating preferential trade agreements in East Asia containing different rules of origins have important implications for economic integration in the region. The expansion of separate FTAs is likely to increase administrative costs for traders. If rules of origins are considerably different between agreements, not only administrative costs but also production costs would be higher for firms. Costs caused by these differences are likely to be higher for small producers than for large producers operating in the hubs. The costs of operating in several preferential trade agreements might become so high that producers in the spoke countries might only be able to trade under one single preferential channel. Extending the same cumulation and origin determination rules between FTAs could greatly reduce the costs for traders.

Lessons from EU experience indicate that there are a number of factors which could further lessen the negative effects of restrictive rules of origin schemes. The burden of production costs induced by restrictive rules of origin can be somewhat reduced by allowing less restrictive cumulation rules (such as diagonal or full cumulation), allowing duty drawback, outsourcing and higher de minimis levels. Furthermore, administrative costs can also be reduced by more trader 'friendly' approaches, such as using self-certification methods.

The empirical analysis conducted in this paper aimed to assess the potential impact of preferences on trade flows under AFTA and to provide an approximation for the costs of requesting preferences. Although the empirical analysis could not be carried out using data on utilization of preferential tariffs, nevertheless the results suggest that CEPT tariffs might be expected to be exploited when difference between third country tariffs and preferential tariffs are higher than 10-25 percent. According to our estimate the positive effects of preferences becomes significant when the preference margin is higher than 25 percent which covers $9.2 \%$ of total sum of tariff lines in Indonesia, Malaysia, Philippines and Thailand, and accounts for $7.8 \%$ of the aggregate value of their joint imports. The rough utilization rate estimate of 5\% (of total import value) based on firm interviews thus comes rather close to the regression estimates derived here.

The effects of margins below $5 \%$, and those above $80 \%$ have a significant negative effect on trade flows; the former implying that administrative and other costs related to obtaining preferences exceed the benefits due to margins; and the latter due to the larger incidence of NTMs in these products, or the simultaneous implementation of a regional program which is exerting a more determinant role on production and trading patterns.

The proliferation of overlapping FTAs, and the resulting increase in the potential back-doors through which preferences could spill-over to non-partners, have made the imposition of rules of origin an ever more important instrument to ward off trade deflection. The findings in this paper, however, highlight the complexities and the consequent costs brought about by the implementation of 
these rules. Whether or not the rules of origin as they are now, will be kept as a necessary good, or discarded as an unnecessary evil inevitably depends on whether FTAs are motivated by regional import-substitution or by a truly outward-oriented trade policy strategy. 


\section{References}

Brenton, P., 2003. 'Notes on Rules of Origin with Implications for Regional Integration in South East Asia', World Bank, Washington DC, mimeo

Brenton, P., Manchin, M., 2003. Making EU Trade Agreements Work: The Role of Rules of Origin. World Economy, May 2003, vol. 26, no. 5, pp. 755-769

Cadot, O., Carrere, C., De Melo, J., Tumurchudur, B., 2005. Product Specific Rules of Origin in EU and US Preferential Trading Agreements: An Assessment, CEPR Discussion Paper No. 4998

Carrière, C., de Melo, J., 2004. Are Different Rules of Origin Equally Costly? Estimates from NAFTA. CEPR Discussion Paper No. 4437.

Estevadeordal, A., Suominen, K., 2005. Rules of Origin in Preferential Trading Arrangements: Is All Well with the Spaghetti Bowl in the Americas? Economia 5(2): 63-92.

Herin, J., 1986. Rules of Origin and Differences Between Tariff Levels in EFTA and in the EC. EFTA Secretariat, Geneva.

Hoekman, B., 1993. Rules of Origin for Goods and Services, Conceptual Issues and Economic Considerations, Journal of World Trade, 27 (4):81-99.

Inama, S., 2003. Trade Preferences for LDCs: An Early Assessment of Benefits and

Possible Improvements. UNCTAD, ITCD/TSB/2003.

JETRO, 2004. “ASEAN's FTAs and Rules of Origin,” Japan External Trade Organization Overseas Research Department

Manchin, M., 2006. Preference utilisation and tariff reduction in EU imports from ACP countries. World Economy, forthcoming.

Manchin, M., Pelkmans-Balaoing, A., 2006. Clothes without an Emperor: Analysis of the Preferential Tariffs in ASEAN. Tinbergen Institute Discussion Paper Series. Rotterdam.

Zedillo, E., P. Messerlin, Nielson, J., 2005. Trade for Development Task Force on Trade. UN Millennium Project, London.

Web Sources used for FTA Rules of Origin Agreements:

http://app.fta.gov.sg/asp/fta/ourfta.asp (for Singapore- Australia; Singapore - New Zealand; Singapore-Japan; Singapore-Korea; Singapore- New Zealand; Transpacific SEP)

http://www.aseansec.org/12025.htm (for AFTA; ASEAN-China; ASEAN-Korea)

http://www.bilaterals.org/article.php3?id article=3564 (for Japan-Malaysia EPA)

http://www.dfat.gov.au/geo/new zealand/anz cer/anz cer.html (for Australia-New Zealand CER)

http://www.dfat.gov.au/trade/negotiations/aust-thai/tafta toc.html (for Thailand-Australia Free Trade Area)

http://www.mfat.govt.nz/tradeagreements/thainzcep/thaiindex.html (for Thailand-New Zealand CEP) 


\section{Tables}

Table 1: Import content of selected sectors in East Asia, 2001

\begin{tabular}{|c|c|c|c|c|c|c|c|c|c|}
\hline & \multicolumn{9}{|c|}{ Sectors } \\
\hline country & textiles & clothing & leather & chem & $\begin{array}{l}\text { motor } \\
\text { vehicles }\end{array}$ & $\begin{array}{l}\text { transp } \\
\text { equipt. }\end{array}$ & $\begin{array}{l}\text { elect. } \\
\text { mach. }\end{array}$ & $\begin{array}{l}\text { mach \& } \\
\text { equipt }\end{array}$ & $\begin{array}{l}\text { other } \\
\mathrm{mfg} \text {, }\end{array}$ \\
\hline \multirow[t]{2}{*}{ Indonesia } & 27.42 & 6.56 & 8.44 & 29.33 & 25.12 & 40.09 & 23.09 & 56.88 & 9.37 \\
\hline & 7.78 & 15.52 & 5.51 & 4.52 & 6.01 & 3.25 & 6.83 & 2.52 & 2.05 \\
\hline \multirow[t]{2}{*}{ Malaysia } & 38.04 & 39.24 & 73.23 & 27.36 & 35.95 & 29.53 & 44.08 & 34.10 & 39.92 \\
\hline & 10.02 & 9.37 & 4.70 & 4.93 & 7.25 & 5.62 & 2.83 & 7.99 & 6.13 \\
\hline \multirow[t]{2}{*}{ Philippines } & 37.80 & 40.71 & 26.72 & 38.67 & 44.94 & 23.72 & 70.23 & 56.62 & 18.67 \\
\hline & 13.02 & 14.30 & 8.46 & 13.23 & 17.14 & 7.28 & 45.02 & 31.26 & 4.14 \\
\hline \multirow[t]{2}{*}{ Singapore } & 51.15 & 44.35 & 34.56 & 42.19 & 41.75 & 36.17 & 83.19 & 58.24 & 46.29 \\
\hline & 6.57 & 5.71 & 6.28 & 3.07 & 4.68 & 7.37 & 1.42 & 2.51 & 0.00 \\
\hline \multirow[t]{2}{*}{ Thailand } & 23.26 & 12.95 & 26.08 & 22.72 & 38.07 & 63.94 & 57.22 & 48.86 & 27.60 \\
\hline & 6.64 & 10.50 & 5.05 & 2.33 & 8.53 & 5.67 & 5.23 & 3.85 & 0.00 \\
\hline \multirow[t]{2}{*}{ ASEAN } & 35.53 & 28.76 & 33.81 & 32.05 & 37.16 & 38.69 & 55.56 & 50.94 & 28.37 \\
\hline & 8.81 & 11.08 & 6.00 & 5.62 & 8.72 & 5.84 & 12.27 & 9.63 & 2.46 \\
\hline \multirow[t]{2}{*}{$\begin{array}{l}\text { rest of } \\
\text { ASEAN }\end{array}$} & 23.26 & 12.95 & 26.08 & 22.72 & 38.07 & 63.94 & 57.22 & 48.86 & 27.60 \\
\hline & 5.37 & 6.13 & 4.29 & 2.89 & 5.05 & 5.45 & 3.75 & 2.44 & 3.31 \\
\hline \multirow[t]{2}{*}{ China } & 11.00 & 10.60 & 8.33 & 12.84 & 12.69 & 11.50 & 35.65 & 13.46 & 8.63 \\
\hline & 4.78 & 5.11 & 3.72 & 3.63 & 5.47 & 5.13 & 7.57 & 3.89 & 2.78 \\
\hline \multirow[t]{2}{*}{ Japan } & 10.17 & 6.95 & 11.10 & 8.44 & 1.67 & 5.11 & 8.23 & 5.29 & 6.12 \\
\hline & 3.26 & 2.83 & 2.41 & 2.87 & 1.66 & 1.69 & 2.49 & 1.48 & 1.43 \\
\hline \multirow[t]{2}{*}{ Korea } & 19.31 & 16.02 & 35.11 & 19.51 & 10.13 & 18.26 & 36.50 & 17.81 & 15.48 \\
\hline & 8.17 & 8.31 & 6.41 & 8.73 & 7.41 & 5.33 & 6.41 & 4.62 & 5.16 \\
\hline \multirow[t]{2}{*}{ Australia } & 14.15 & 29.72 & 22.08 & 17.98 & 24.02 & 24.91 & 32.46 & 20.25 & 13.01 \\
\hline & 13.82 & 20.96 & 21.00 & 18.84 & 16.81 & 15.89 & 11.20 & 12.89 & 10.25 \\
\hline \multirow[t]{2}{*}{ New Zealand } & 14.15 & 29.72 & 22.08 & 17.98 & 24.02 & 24.91 & 32.46 & 20.25 & 13.01 \\
\hline & 13.82 & 20.96 & 21.00 & 18.84 & 16.81 & 15.89 & 11.20 & 12.89 & 10.25 \\
\hline
\end{tabular}

Source: Authors' calculations based on WITS trade data 
Table 2: Rules of Origin in East Asian FTAs

\begin{tabular}{|c|c|c|c|c|c|}
\hline & $\begin{array}{l}\text { Change of } \\
\text { Tariff } \\
\text { Classification }\end{array}$ & $\begin{array}{l}\text { Value Added } \\
\text { Dom. or } \\
\text { Import Content }\end{array}$ & $\begin{array}{l}\text { Specific } \\
\text { Manufacturing } \\
\text { Process }\end{array}$ & Cumulation & Tolerance \\
\hline $\begin{array}{l}\text { ASEAN FTA } \\
\text { (AFTA) }\end{array}$ & $\mathrm{Yes}^{29}$ & Regional (40\%) & & diagonal & \\
\hline $\begin{array}{l}\text { ASEAN-China } \\
\text { (ACFTA) }\end{array}$ & Yes & Regional (40\%) & & diagonal & \\
\hline $\begin{array}{l}\text { ASEAN-Korea } \\
\text { (AKFTA) }\end{array}$ & Yes & Regional (40\%) & & diagonal & \\
\hline $\begin{array}{l}\text { Singapore - } \\
\text { Japan (JSEPA) }\end{array}$ & Yes & Dom. $(60 \%)$ & Yes & Bilateral & product specific \\
\hline $\begin{array}{l}\text { Singapore - } \\
\text { New } \\
\text { Zealand } \\
\text { (ANZSCEP) }\end{array}$ & & Dom. $40 \%$ & & Bilateral & 10 \\
\hline $\begin{array}{l}\text { Singapore - } \\
\text { Australia } \\
\text { (SAFTA) }\end{array}$ & & $\begin{array}{l}\text { Dom. } \\
50 \% \text { (30\% for } \\
\text { some } \\
\text { products) }\end{array}$ & & & $3 \%$ \\
\hline $\begin{array}{l}\text { Singapore- } \\
\text { Korea (KSFTA) }\end{array}$ & Yes & $45-55 \%$ & & Bilateral & $10 \% 0^{30}$ \\
\hline $\begin{array}{l}\text { Thailand- } \\
\text { Australia } \\
\text { (TAFTA) }\end{array}$ & Yes & $40-45 \%$ & Yes & Bilateral & $10 \%$ \\
\hline $\begin{array}{l}\text { Thailand- NZ } \\
\text { TNZCEP }\end{array}$ & $\begin{array}{l}\text { Yes, product } \\
\text { spec. }\end{array}$ & & Yes & Bilateral & $10 \%$ \\
\hline $\begin{array}{l}\text { Malaysia-Japan } \\
\text { (JMEPA) }\end{array}$ & $\begin{array}{l}\text { Yes, product } \\
\text { spec. }\end{array}$ & $\begin{array}{l}\text { Dom. } 40 \% \\
\text { (product } \\
\text { specific) }\end{array}$ & & Bilateral & $\begin{array}{l}\text { Only from } \\
\text { ASEAN } \\
\text { (product } \\
\text { specific) }\end{array}$ \\
\hline $\begin{array}{l}\text { Trans-Pacific } \\
\text { TRANSEP }\end{array}$ & Yes & $45-50 \%$ & Yes & Diagonal & $10 \%$ \\
\hline $\begin{array}{l}\text { Australia - NZ } \\
\text { (ANZCER) }\end{array}$ & & $50 \%$ & & Bilateral & $2 \%$ \\
\hline
\end{tabular}

${ }^{29}$ Applicable for textiles, and wood-based products, iron \& steel as an alternative rule, and for wheat \& flour as an exclusive rule.

${ }^{30}$ For yarns and fibres used for clothing and textiles products $8 \%$ applies; the de minimis rule does not apply to agricultural products or applies with restrictions.

31 Strategic Economic Partnership (SEP); members: Brunei, New Zealand, Chile and Singapore. 
Table 3: Importance of preferences in 2001/2003 (in thousand US\$)

\begin{tabular}{|c|c|c|c|c|c|c|c|c|c|c|c|c|c|c|}
\hline & \multicolumn{6}{|c|}{ CEPT Rates } & \multicolumn{5}{|c|}{ Preference Margins } & \multicolumn{3}{|c|}{ Most common CEPT } \\
\hline & & $0.5-5$ & $6-10$ & $11-15$ & $15<$ & excl/sp & & $0.5-5$ & $6-10$ & $11-15$ & $15<$ & 0 & 3 & 5 \\
\hline \multicolumn{15}{|l|}{ Indonesia } \\
\hline \multirow[t]{2}{*}{2001} & 40.58 & 53.06 & 2.91 & 0.36 & 0 & 3.21 & 52.28 & 37.54 & 5.16 & 0.43 & 1.38 & 40.58 & & 20.01 \\
\hline & 29.41 & 66.59 & 3.23 & 0.74 & 0.63 & & & & & & & 29.41 & & 49.06 \\
\hline \multirow[t]{2}{*}{2003} & 38.38 & 44.35 & 3.19 & 4.17 & 0 & 9.92 & 51.38 & 25.21 & 6.99 & 1.49 & 5.9 & 38.38 & & 30.00 \\
\hline & 28.59 & 66.62 & 3.86 & 0.87 & 0.04 & & & & & & & 28.59 & & 51.84 \\
\hline \multicolumn{15}{|l|}{ Malaysia } \\
\hline \multirow[t]{2}{*}{2001} & 68.57 & 27.91 & 1.81 & 0.54 & 0.09 & 1.08 & 80.19 & 5.39 & 4.32 & 5.38 & 3.64 & 68.57 & & 9.9 \\
\hline & 49.29 & 7.25 & 2.33 & 0.74 & 0.04 & & & & & & & 49.29 & & 32.03 \\
\hline \multirow[t]{2}{*}{2003} & 66.79 & 28.9 & 1.7 & 0.36 & 1.38 & 0.88 & 78.67 & 4.92 & 4.7 & 5.84 & 3.92 & 66.79 & & 9.4 \\
\hline & 49.13 & 43.53 & 4.25 & 2.01 & 0.9 & & & & & & & 49.13 & & 31.98 \\
\hline \multicolumn{15}{|l|}{ Philippines } \\
\hline \multirow[t]{2}{*}{2001} & 43.6 & 52.08 & 2.46 & 0.82 & 0.18 & 0.86 & 64.33 & 26.97 & 4.91 & 1.23 & 0.65 & 43.6 & 33.25 & 10.4 \\
\hline & 17.89 & 77.5 & 3.93 & 0.36 & 0.34 & & & & & & & 17.89 & 40.34 & 31.07 \\
\hline \multirow[t]{2}{*}{2003} & 52.59 & 41.76 & 3.49 & 0.21 & 0.3 & 2.95 & 65.97 & 24.38 & 4.77 & 2.60 & 1.63 & 52.59 & 30.04 & 11.16 \\
\hline & 18.46 & 76.53 & 4.08 & 0.45 & 0.49 & & & & & & & 18.46 & 39.14 & 31.28 \\
\hline \multicolumn{15}{|l|}{ Thailand } \\
\hline \multirow[t]{2}{*}{2001} & 35.93 & 59.19 & 2.36 & 2.43 & 0.09 & 0.01 & 54.31 & 13.26 & 1.97 & 19.37 & 11.00 & 35.93 & & 32.00 \\
\hline & 4.68 & 84.71 & 5.85 & 4.62 & 0.33 & & & & & & & 4.68 & & 61.02 \\
\hline \multicolumn{15}{|l|}{ ASEAN-4 } \\
\hline \multirow[t]{2}{*}{2001} & 47.17 & 48.06 & 2.38 & 1.04 & 0.09 & 1.29 & 62.78 & 20.79 & 4.09 & 6.60 & 4.17 & 47.17 & & 18.08 \\
\hline & 25.32 & 59.01 & 3.84 & 1.62 & 0.34 & & & & & & & 25.32 & & 43.3 \\
\hline \multirow[t]{2}{*}{2003} & 52.59 & 38.33 & 2.79 & 1.58 & 0.56 & 4.58 & 65.34 & 18.17 & 5.49 & 3.31 & 3.82 & 52.59 & & 16.85 \\
\hline & 32.06 & 62.23 & 4.06 & 1.11 & 0.48 & & & & & & & 47.78 & & 44.39 \\
\hline
\end{tabular}

Note: Shares in terms of total tariff lines (HS6) are reported in italics.

Data for Thailand is incomplete for the year 2003.

Source: Manchin \& Pelkmans-Balaoing (2006) 
Table 4: OLS regressions results

\begin{tabular}{|c|c|c|}
\hline dependent variable: $\log$ of & & \\
\hline \multirow[t]{2}{*}{ Ldistance } & -0.211 & -0.214 \\
\hline & $(0.041)^{* * *}$ & $(0.041)^{* * *}$ \\
\hline \multirow[t]{2}{*}{ Common language } & 0.188 & 0.188 \\
\hline & $(0.055)^{* * *}$ & $(0.055)^{* * *}$ \\
\hline \multirow[t]{2}{*}{ Difference1 $(0-5)^{*}$} & -0.059 & -0.057 \\
\hline & $(0.026)^{* *}$ & $(0.026)^{* *}$ \\
\hline \multirow[t]{2}{*}{ Difference2 (5-10) } & -0.034 & -0.031 \\
\hline & $(0.036)$ & $(0.036)$ \\
\hline \multirow[t]{2}{*}{ difference3 (10-15) } & 0.018 & 0.018 \\
\hline & $(0.047)$ & $(0.047)$ \\
\hline \multirow[t]{2}{*}{ difference4 (15-20) } & 0.045 & 0.049 \\
\hline & $(0.057)$ & $(0.056)$ \\
\hline \multirow[t]{2}{*}{ difference5 (20-25) } & 0.092 & 0.094 \\
\hline & $(0.070)$ & $(0.070)$ \\
\hline \multirow[t]{2}{*}{ difference6 (25-30) } & 0.194 & 0.197 \\
\hline & $(0.081)^{* *}$ & $(0.081)^{* *}$ \\
\hline \multirow[t]{2}{*}{ difference7 (30-35) } & 0.392 & 0.392 \\
\hline & $(0.119)^{* * *}$ & $(0.119)^{* * *}$ \\
\hline \multirow[t]{2}{*}{ difference8 (35-40) } & 0.339 & 0.337 \\
\hline & $(0.181)^{*}$ & $(0.181)^{*}$ \\
\hline \multirow[t]{2}{*}{ difference9 (40-45) } & 1.080 & 1.085 \\
\hline & $(0.333)^{* * *}$ & $(0.333)^{* * *}$ \\
\hline \multirow[t]{2}{*}{ difference10 (45-50) } & 0.968 & 0.934 \\
\hline & $(0.277)^{* * *}$ & $(0.277)^{* * *}$ \\
\hline \multirow[t]{2}{*}{ difference11 (50-60) } & 0.700 & 0.695 \\
\hline & $(0.352) * *$ & $(0.351)^{* *}$ \\
\hline \multirow[t]{2}{*}{ difference12 (60-70) } & -0.310 & -0.300 \\
\hline & $(1.119)$ & $(1.119)$ \\
\hline \multirow[t]{2}{*}{ difference13 (70-80) } & 4.020 & 4.044 \\
\hline & $(2.259)^{*}$ & $(2.258)^{*}$ \\
\hline \multirow[t]{2}{*}{ difference14 (80-90) } & -11.106 & -11.067 \\
\hline & $(4.455)^{* *}$ & $(4.451)^{* *}$ \\
\hline \multirow[t]{2}{*}{ difference15 (90- } & -5.155 & -5.176 \\
\hline & $(2.329)^{* *}$ & $(2.327)^{* *}$ \\
\hline \multirow[t]{2}{*}{ Substantial transformation } & & -0.932 \\
\hline & & $(0.112)^{* * *}$ \\
\hline Observations & 42268 & 42268 \\
\hline R-squared & 0.11 & 0.11 \\
\hline
\end{tabular}

$*$ Difference between preferential and MFN tariffs (in \% points) in parenthesis

Time fixed effects; sectoral dummies and time varying sector-specific reporter and partner fixed effects are included in the regressions. Standard errors in parentheses

* significant at $10 \%$; ** significant at $5 \%$; *** significant at $1 \%$ 
Table 5: Incidence of non-tariff measures on products with high preferential margins (2003)

\begin{tabular}{|c|c|c|c|c|}
\hline high margin products & $\begin{array}{l}\text { HS6 } \\
\text { code }\end{array}$ & $\begin{array}{l}\text { preference } \\
\text { margin of } \\
(\text { in } \%)\end{array}$ & $\begin{array}{l}\text { share of intra- } \\
\text { ASEAN4 trade }\end{array}$ & NTM incidence* \\
\hline Compound alcoholic preparations & 330210 & $\begin{array}{l}\mathbf{8 7 . 5} \\
\text { IDN } \\
(0 \quad \text { SGP, } \\
\text { MYS }) \\
(1 \quad \text { PHL }) \\
(5 \text { THA })\end{array}$ & $\begin{array}{c}10.96 \\
(2.06)^{* *}\end{array}$ & \\
\hline women's/girls' silk blouses & 620610 & $\begin{array}{l}\mathbf{6 0 . 0} \\
\text { THA } \\
\text { (0 SGP; } \\
13.75 \text { IDN; } \\
15 \text { MYS) } \\
\end{array}$ & $\begin{array}{c}5.58 \\
(5.48)\end{array}$ & Thailand - import license \\
\hline $\begin{array}{l}\text { Vehicles specially designed for } \\
\text { travelling on snow, golf cars \& } \\
\text { similar vehicles }\end{array}$ & 870310 & $\begin{array}{l}\mathbf{7 0 . 0} \\
\text { IDN } \\
(23.36 \\
\text { MYS })\end{array}$ & $\begin{array}{c}1.7 \\
(0.0)\end{array}$ & $\begin{array}{l}\text { Indonesia }-6100,8100 \\
\text { Malaysia }-6170\end{array}$ \\
\hline $\begin{array}{l}\text { Vehicles w/ spark-ignition internal } \\
\text { combustion reciprocating piston } \\
\text { engine, of a cylinder capacity } \\
\text { exceeding } 1,500 \mathrm{cc} \text { but not } \\
\text { exceeding } 3000 \mathrm{~cm} 3\end{array}$ & 870323 & $\begin{array}{ll}\mathbf{1 0 0 . 6} & \text { MYS } \\
65.0 & \\
\text { THA } & \\
36.67 & \text { IDN } \\
25.0 & \text { PHL }\end{array}$ & $\begin{array}{l}10.74 \\
(10.7)\end{array}$ & $\begin{array}{l}\text { Indonesia }-6100,8100 \\
\text { Malaysia }-6100 \\
\text { Philippines }-6100 \\
\text { Thailand }-6170\end{array}$ \\
\hline $\begin{array}{l}\text { Vehicles w/ spark-ignition internal } \\
\text { combustion reciprocating piston } \\
\text { engine, Of a cylinder capacity } \\
\text { exceeding } 3,000 \mathrm{cc}\end{array}$ & 870324 & $\begin{array}{ll}148.85 & \text { MYS } \\
57.5 & \\
\text { THA } & \\
40.0 & \\
\end{array}$ & $\begin{array}{c}0.7 \\
(0.6)\end{array}$ & $\begin{array}{l}\text { Indonesia }-6100,8100 \\
\text { Malaysia - } 6100 \\
\text { Philippines }-6100 \\
\text { Thailand }-6170 \\
\end{array}$ \\
\hline $\begin{array}{l}\text { Vehicles w/ compression- ignition } \\
\text { internal combustion piston engine } \\
\text { (Diesel / semidiesel), Of a cylinder } \\
\text { capacity exceeding } 1,500 \mathrm{cc} \text { but not } \\
\text { exceeding } 2500 \mathrm{~cm} 3\end{array}$ & 870332 & $\begin{array}{ll}36.67 & \text { IDN } \\
25.0 & \text { PHL }\end{array}$ & $\begin{array}{c}1.4 \\
(1.4)\end{array}$ & $\begin{array}{l}\text { Indonesia }-6100,8100 \\
\text { Malaysia }-6100 \\
\text { Philippines }-6100 \\
\text { Thailand }-6170\end{array}$ \\
\hline $\begin{array}{l}\text { Vehicles w/ compression- ignition } \\
\text { internal combustion piston engine } \\
\text { (Diesel / semidiesel), Of a cylinder } \\
\text { capacity exceeding 2,500 cc }\end{array}$ & 870333 & $\begin{array}{ll}148.33 & \text { MYS } \\
40.0 & \text { IDN } \\
25 & \text { PHL }\end{array}$ & $\begin{array}{c}0.9 \\
(0.9)\end{array}$ & $\begin{array}{l}\text { Indonesia }-6100,8100 \\
\text { Malaysia }-6100 \\
\text { Philippines }-6100 \\
\text { Thailand }-6170 \\
\end{array}$ \\
\hline $\begin{array}{l}\text { Components, parts, accessories for } \\
\text { assembly of motor vehicles }\end{array}$ & 870390 & $\begin{array}{cl}100.6 & \text { MYS } \\
75.0 & \text { IDN }\end{array}$ & $\begin{array}{l}10.3 \\
(9.6)\end{array}$ & $\begin{array}{l}\text { Indonesia }-6100,8100 \\
\text { Malaysia }-6100 \\
\text { Philippines }-6100 \\
\text { Thailand }-6170 \\
\end{array}$ \\
\hline $\begin{array}{l}\text { Bodies (incldg cabs), for the } \\
\text { vehicles of hdg. } 8703\end{array}$ & 870710 & $\begin{array}{ll}\mathbf{7 5 . 0} & \text { THA } \\
25.0 & \text { MYS } \\
\end{array}$ & $\begin{array}{c}45.69 \\
(45.69) \\
\end{array}$ & Malaysia -6170 \\
\hline $\begin{array}{l}\text { Bodies (incldg. cabs), for the } \\
\text { vehicles of hdg. } 8701 \text { to } 8705 \text {, excl. } \\
8703\end{array}$ & 870790 & $\begin{array}{ll}75.0 & \text { THA }\end{array}$ & $\begin{array}{c}7.3 \\
(6.0)\end{array}$ & \\
\hline $\begin{array}{l}\text { Motorcycles w/ reciprocating } \\
\text { internal combustion piston engine }\end{array}$ & 870020 & $\begin{array}{ll}\mathbf{6 7 . 0} & \text { THA } \\
36.45 & \text { MYS } \\
25.0 & \text { IDN } \\
25.0 & \text { PHL } \\
\end{array}$ & $\begin{array}{l}7.3 \\
(7.3)\end{array}$ & \\
\hline
\end{tabular}

* Source: ASEAN Secretariat database of Non-Tariff Measures

$* *$ Share of intra-ASEAN10 trade in parenthesis

Note: NTM codes: 6100 - non-automatic licensing (quantity control measure); 6170 - non-automatic licensing (discretionary import license); 8100 - Technical regulations. 
Table 6: Breakdown of intra-ASEAN trade according to preferential margins

\begin{tabular}{|c|c|c|c|c|c|c|c|}
\hline & \multicolumn{2}{|c|}{ Above $60 \%$} & \multicolumn{2}{|c|}{ Between 60 and $25 \%$} & \multicolumn{2}{|c|}{ Below 25\% } & \multirow{2}{*}{$\begin{array}{c}\text { Total eligible } \\
\text { trade }\end{array}$} \\
\hline & value & $\begin{array}{c}\text { Share of } \\
\text { total }\end{array}$ & value & $\begin{array}{c}\text { Share of } \\
\text { total }\end{array}$ & value & $\begin{array}{c}\text { Share of } \\
\text { total }\end{array}$ & \\
\hline \multicolumn{8}{|l|}{ Indonesia } \\
\hline number of product codes & 15 & $0.2 \%$ & 60 & $0.9 \%$ & 6261 & $98.8 \%$ & 6336 \\
\hline value of imports & 13892 & $0.3 \%$ & 277840 & $5.9 \%$ & 4390452 & $93.8 \%$ & 4682184 \\
\hline \multicolumn{8}{|l|}{ Malaysia } \\
\hline number of product codes & 17 & $0.1 \%$ & 1367 & $10.8 \%$ & 11288 & $89.1 \%$ & 12672 \\
\hline value of imports & 8023 & $0.1 \%$ & 784266 & $5.0 \%$ & 14843424 & $94.9 \%$ & 15635714 \\
\hline \multicolumn{8}{|l|}{ Philippines } \\
\hline number of product codes & 0 & $0.0 \%$ & 96 & $0.8 \%$ & 12077 & $99.2 \%$ & 12173 \\
\hline value of imports & 0 & $0.0 \%$ & 86117 & $1.7 \%$ & 4952212 & $98.3 \%$ & 5038329 \\
\hline \multicolumn{8}{|l|}{ Thailand } \\
\hline number of product codes & 16 & $0.1 \%$ & 2365 & $21.3 \%$ & 8706 & $78.5 \%$ & 11087 \\
\hline value of imports & 211705 & $2.1 \%$ & 1651128 & $16.0 \%$ & 8449928 & $81.9 \%$ & 10312761 \\
\hline \multicolumn{8}{|l|}{ Total } \\
\hline number of product codes & 48 & $0.1 \%$ & 3888 & $9.2 \%$ & 38332 & $90.7 \%$ & 42268 \\
\hline value of imports & 233620 & $0.7 \%$ & 2799351 & $7.8 \%$ & 32636016 & $91.5 \%$ & 35668987 \\
\hline
\end{tabular}

